\title{
Assessment of the Losses Due to Self Absorption by Mass Loading on Radioactive Particulate Air Stack Sample Filters
}

BM Smith

JM Barnett

MY Ballinger

January 2011 


\title{
DISCLAIMER
}

This report was prepared as an account of work sponsored by an agency of the United States Government. Neither the United States Government nor any agency thereof, nor Battelle Memorial Institute, nor any of their employees, makes any warranty, express or implied, or assumes any legal liability or responsibility for the accuracy, completeness, or usefulness of any information, apparatus, product, or process disclosed, or represents that its use would not infringe privately owned rights. Reference herein to any specific commercial product, process, or service by trade name, trademark, manufacturer, or otherwise does not necessarily constitute or imply its endorsement, recommendation, or favoring by the United States Government or any agency thereof, or Battelle Memorial Institute. The views and opinions of authors expressed herein do not necessarily state or reflect those of the United States Government or any agency thereof.

\author{
PACIFIC NORTHWEST NATIONAL LABORATORY \\ operated by \\ BATTELLE \\ for the \\ UNITED STATES DEPARTMENT OF ENERGY \\ under Contract DE-AC05-76RL01830
}

Printed in the United States of America

Available to DOE and DOE contractors from the

Office of Scientific and Technical Information,

P.O. Box 62, Oak Ridge, TN 37831-0062;

ph: (865) 576-8401

fax: $(865) 576-5728$

email: reports@adonis.osti.gov

\footnotetext{
Available to the public from the National Technical Information Service, U.S. Department of Commerce, 5285 Port Royal Rd., Springfield, VA 22161 ph: (800) 553-6847 fax: $(703) 605-6900$

email: orders@ntis.fedworld.gov

online ordering: http://www.ntis.gov/ordering.htm
}

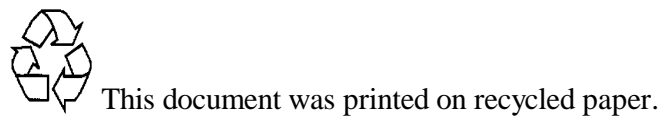




\section{Assessment of the Losses Due to Self Absorption by Mass Loading on Radioactive Particulate Air Stack Sample Filters}

BM Smith

JM Barnett

MY Ballinger

January 2011

Prepared for the U.S. DEPARTMENT OF ENERGY under Contract DE-AC05-76RL01830

Pacific Northwest National Laboratory Richland, WA 99354 


\section{Summary}

This study draws a relationship between filter mass loading, percent loss using the mass loading data collected, and previous studies of self-absorption. The mass loading consists of particulate dust, radioactive particulates, and filter material. A study by Higby [1984] calculated a minimum burial depth for an alpha particle to be lost due to absorption (100\% loss) of about $3.7 \mathrm{mg} \mathrm{cm}^{-2}$ based on calculations for the range of ${ }^{239} \mathrm{Pu}$ alpha particles in glass fiber filters. Luetzelschwab et al. [2000] recommended assuming a $40 \%$ loss at a loading of $3.3 \mathrm{mg} \mathrm{cm}^{-2}$ and a $28 \%$ loss for a loading of $2.3 \mathrm{mg} \mathrm{cm}^{-2}$. Mass loadings in this latter study included dust loading plus the mass of the front layer of filter. This study examined light dust loadings (averaging about $0.1 \mathrm{mg} \mathrm{cm}^{-2}$ ) on filter material and compared this with other literature data to estimate losses at typical mass loadings on filters from PNNL sampled exhaust sites.

During an 18-month period, 116 samples were collected and analyzed from 8 different building stacks. Under normal operating conditions at the stacks monitored by Effluent Management, the mass loading of sample filters averages $0.09 \pm 0.12(2 \sigma) \mathrm{mg} \mathrm{cm}^{-2}$ (excluding negative values and outliers) and ranges from $0 \mathrm{mg} \mathrm{cm}^{-2}$ to $0.24 \mathrm{mg} \mathrm{cm}^{-2}$. This study presents two different methods of relating percent loss due to selfabsorption to filter mass loading: exponential and linear relationships based on data from Luetzelschwab et al. [2000] and Higby [1984]. In general, samples have losses of less than $19 \%$ using the conservative exponential model and less than $7 \%$ using the linear model; therefore, a correction factor of 0.85 remains conservative.

For higher accuracy, the Effluent Management group recommends that each filter be weighed before and after installation on the sampling system. Having tare weights and gross weights allow the mass loading of each filter and any applicable correction factors to be determined on a case-by-case basis. 


\section{Acknowledgments}

The authors would like to acknowledge the support of Betty Anderson, Truc Trang-Le, Lisa Staudinger, Kathie Thomas, and Brian Walker. 


\section{Acronyms and Initialisms}

$\begin{array}{ll}\text { ANSI } & \text { American National Standards Institute } \\ \text { EM } & \text { Effluent Management group } \\ \text { HEPA } & \text { High-Efficiency Particulate Air } \\ \text { HPS } & \text { Health Physics Society } \\ \text { ID } & \text { Identification } \\ \text { PNNL } & \text { Pacific Northwest National Laboratory }\end{array}$




\section{Contents}

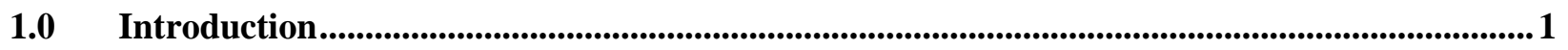

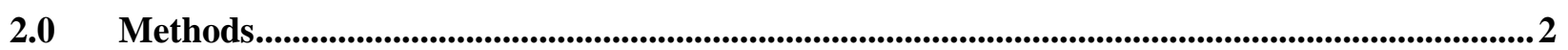

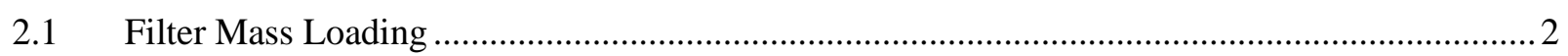

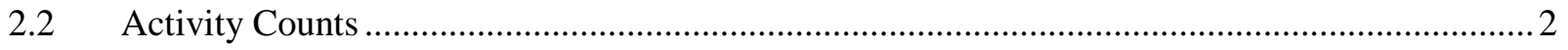

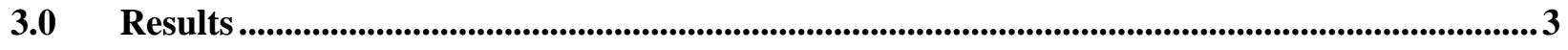

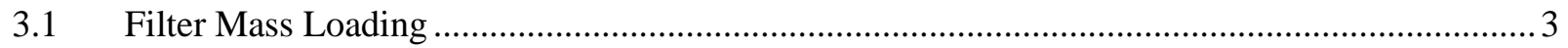

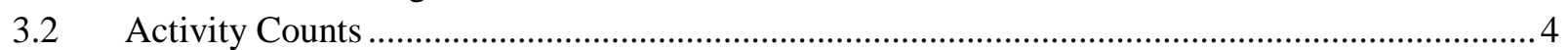

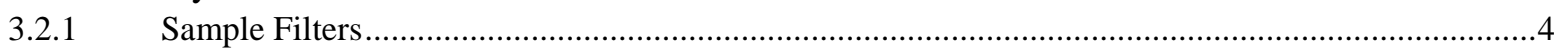

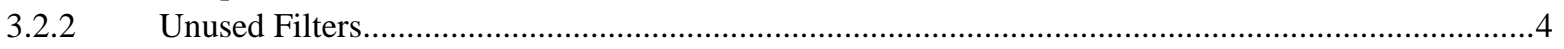

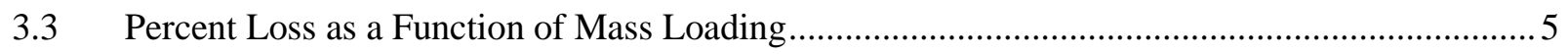

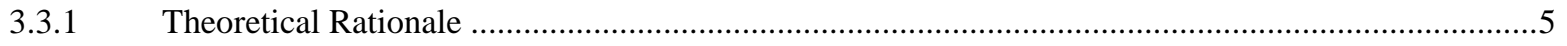

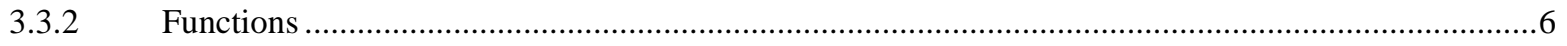

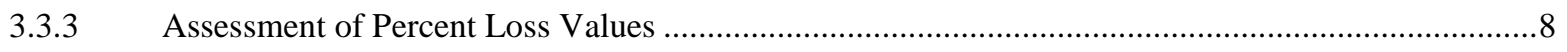

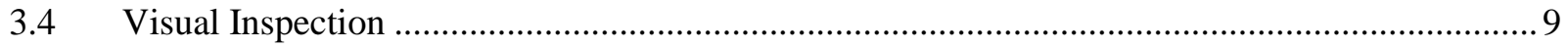

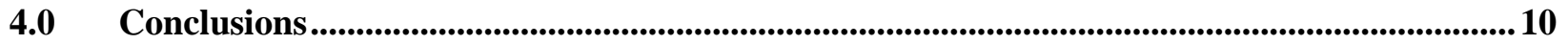

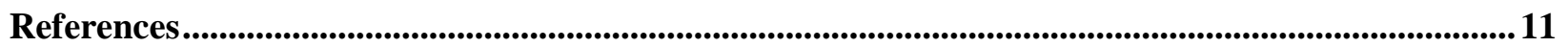




\section{Figures}

Figure 1: Histogram of Mass Loading in Milligrams Measured on Filters from Sampling

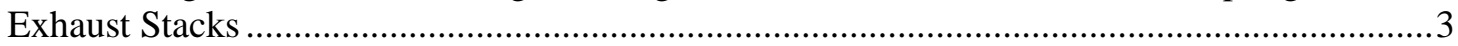

Figure 2: Exponential Relationship of Known Values ….....................................................

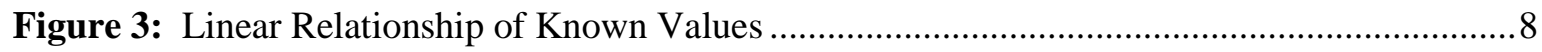

\section{Tables}

Table 1: Background Activity of Unused Filters .....................................................................

Table 2: Percent Loss at Typical Average and Upper Bound Mass Loadings................................9

Table 3: Percent Loss at Atypical Mass Loadings ................................................................. 


\subsection{Introduction}

In order to perform environmental monitoring of air emissions from laboratories that have the potential to emit radioactive particles, the Effluent Management group (EM) of the Pacific Northwest National Laboratory (PNNL) coordinates the collection of particulate material from building emission stacks on Versapor ${ }^{\circledR a} 3000$ membrane filters. EM manages the analyses of the filters for alpha and beta activity to determine the total amount of radioactive air emissions. ANSI/HPS N13.1-1999, Sampling and Monitoring Releases of Airborne Radioactive Substances from the Stack and Ducts of Nuclear Facilities, recommends that if the penetration of radioactive material into the filter collection media or self-absorption of radiation by the material collected would reduce the count rate of radioactive particles by more than $5 \%$, a correction factor should be used [ANSI 1999]. Since the mid-1980s, PNNL has used a correction factor for selfabsorption of alpha particles of 0.85 based on similarity of filter media, particle size, and flow rates [Higby 1984, Barnett et al. 2009b]. EM has historically applied the same correction factor equally to samples analyzed for beta particles. This correction factor of 0.85 assumes approximately $15 \%$ losses in the count rate of both alpha and beta particles.

Over an 18-month period from February 2009 to July 2010, EM coordinated an effort to collect and analyze the mass loading from 116 samples from 8 different building stacks. EM also randomly chose 11 unused filters to be analyzed in order to determine background radiation and the theoretical zero mass loading. All of these samples were collected and analyzed in order to evaluate the current correction factor being used.

A previous study [Barnett et al. 2009a] purposed to directly measure the losses due to selfabsorption of filters collected from PNNL facilities. The study first counted the activity directly from the sample filter, then acid-digested the filter, dried the sample material onto a planchet, and measured the activity again. The acid-digestion process should have eliminated the effects of self-absorption or penetration into the collection media. Unexpectedly, the activity measured after digestion was less than that measured before digestion in most of the samples. This was attributed to lack of precision in the digestion, the analysis process, and large instrument sensitivity error at the extremely low levels of radioactivity on the filters. Barnett et al. [2009a] also concluded that the results did not suggest significant particulate penetration through the filter based on visual observation since particles of interest were not observed on the downstream side of the filter.

The Versapor ${ }^{\circledR} 3000$ membrane filters used in this study are composed of an acrylic copolymer on a nylon substrate. They have a 3- $\mu$ m pore size, a 47-mm diameter, and a thickness of about $50 \mu \mathrm{m}$ [Barnett et al. 2009b]. After installation on a fixed-head radioactive air stack sampler, the active diameter decreases to about $41 \mathrm{~mm}\left(13.2 \mathrm{~cm}^{2}\right.$ active sampling area).

The exhaust stream in the emission stack passes through a minimum of one stage of highefficiency particulate air (HEPA) filter. However, in some buildings unfiltered air and the filtered

\footnotetext{
${ }^{a}$ Pall Gelman Versapor ${ }^{\circledR}$ Membranes, Krackeler Scientific, inc., 57 Broadway, Albany, NY 12202.
} 
exhaust may be combined; when this occurs, non-radioactive particles may additionally load the sample filter. The sample flow rates generally range from 28 to $85 \mathrm{~L} \mathrm{~min}^{-1}$, which is on the low end of the filter maximum rated flow rate of $900 \mathrm{~L} \mathrm{~min}^{-1}$. These flow rates correspond to face velocities of 0.35 to $1.1 \mathrm{~ms}^{-1}$. Barnett and Kane [1993] have previously shown that Versapor ${ }^{\circledR}$ 3000 filters with an active sample area of about $5 \mathrm{~cm}^{2}$ may be operated in this range for a week or more in unfiltered systems without sample volume degradation due to particulate loading.

This study purposes to draw a relationship between filter mass loading and percent loss using the data collected and previous studies of self-absorption. The mass loading consists of particulate dust, radioactive particulates, and filter material. A study by Higby [1984] calculated a minimum burial depth for an alpha particle to be lost due to absorption (100\% loss) of about $3.7 \mathrm{mg} \mathrm{cm}^{-2}$ based on calculations for the range of ${ }^{239} \mathrm{Pu}$ alpha particles in glass fiber filters. Luetzelschwab et al. [2000] recommended assuming a $40 \%$ loss at a loading of $3.3 \mathrm{mg} \mathrm{cm}^{-2}$ and a $28 \%$ loss for a loading of $2.3 \mathrm{mg} \mathrm{cm}^{-2}$. Mass loadings in the Luetzelschwab study included dust loading plus the mass of the filter front layer. The results presented in this paper examined light dust loadings (averaging about $0.1 \mathrm{mg} \mathrm{cm}^{-2}$ ) on Versapor ${ }^{\circledR} 3000$ filter material and compared this with other literature data to estimate losses at typical mass loadings on filters from PNNL sampled exhaust sites.

\subsection{Methods}

\subsection{Filter Mass Loading}

EM collected 116 filter samples over an 18-month period from 8 different laboratory emission stacks. Each filter was given a unique identification (ID) number and weighed using a MettlerToledo AT 400 analytical balance ${ }^{\mathrm{b}}$ to determine a tare weight before installation. The sample system pulled a sample of stack effluent air through the filters continuously for 2 weeks.

Researchers then removed each filter from the sampling system and weighed it again to determine the mass loading on the filter, as well as recording a description of visible filter loading (e.g., light dust, medium dust, and dark brown).

\subsection{Activity Counts}

After the above procedure was complete, an LB4100/W Low Background Alpha/Beta Counting System ${ }^{c}$ counted the filter for a standard count time of $10 \mathrm{~min}$ in a $2 \pi$ geometry by gas-flow proportional counting, which has an average alpha detector efficiency of $35 \pm 3 \%$ and an average beta detector efficiency of $55 \pm 3 \%$. An analyst mounted the 47 -mm filter directly on a planchet with the loaded face of the filter exposed and placed double stick tape on a $50.8 \mathrm{~mm}$ diameter by $3.2 \mathrm{~mm}$-deep stainless steel dish and secured the filter using tweezers or a small glass rod to manipulate the filter. If the filter extends beyond the lip of the planchet dish, additional tape may be used to help hold down a curled filter. The detector system uses commercial grade P-10 gas

\footnotetext{
${ }^{\mathrm{b}}$ Mettler-Toledo, Inc., 1900 Polaris Parkway, Columbus, OH 43240.

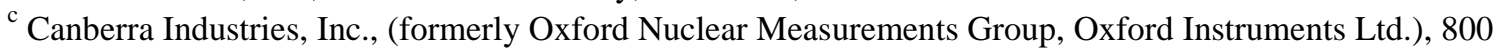
Research Parkway, Meriden, CT 06450.
} 
(90\% argon and 10\% methane) during counting. Adjusting the instrument discriminator settings controls alpha and beta instrument crosstalk.

In order to determine the background activity, the same LB4100/W Low Background Alpha/Beta Counting System analyzed the 11 unused filters for 500 min each.

\subsection{Results}

\subsection{Filter Mass Loading}

EM calculated the filter mass loading values in order to determine the statistical range of typical filter mass loading at PNNL facilities. In later sections, this paper will demonstrate a relationship between filter mass loading and percent loss of alpha activity detection due to self-absorption using previous data, allowing the assessment of the current correction factor of 0.85 for the typical mass loading values from PNNL facilities.

Appendix A shows the data from the 116 filters that were analyzed. Figure 1 is a histogram of the results showing the relative frequency of mass loading in milligrams.

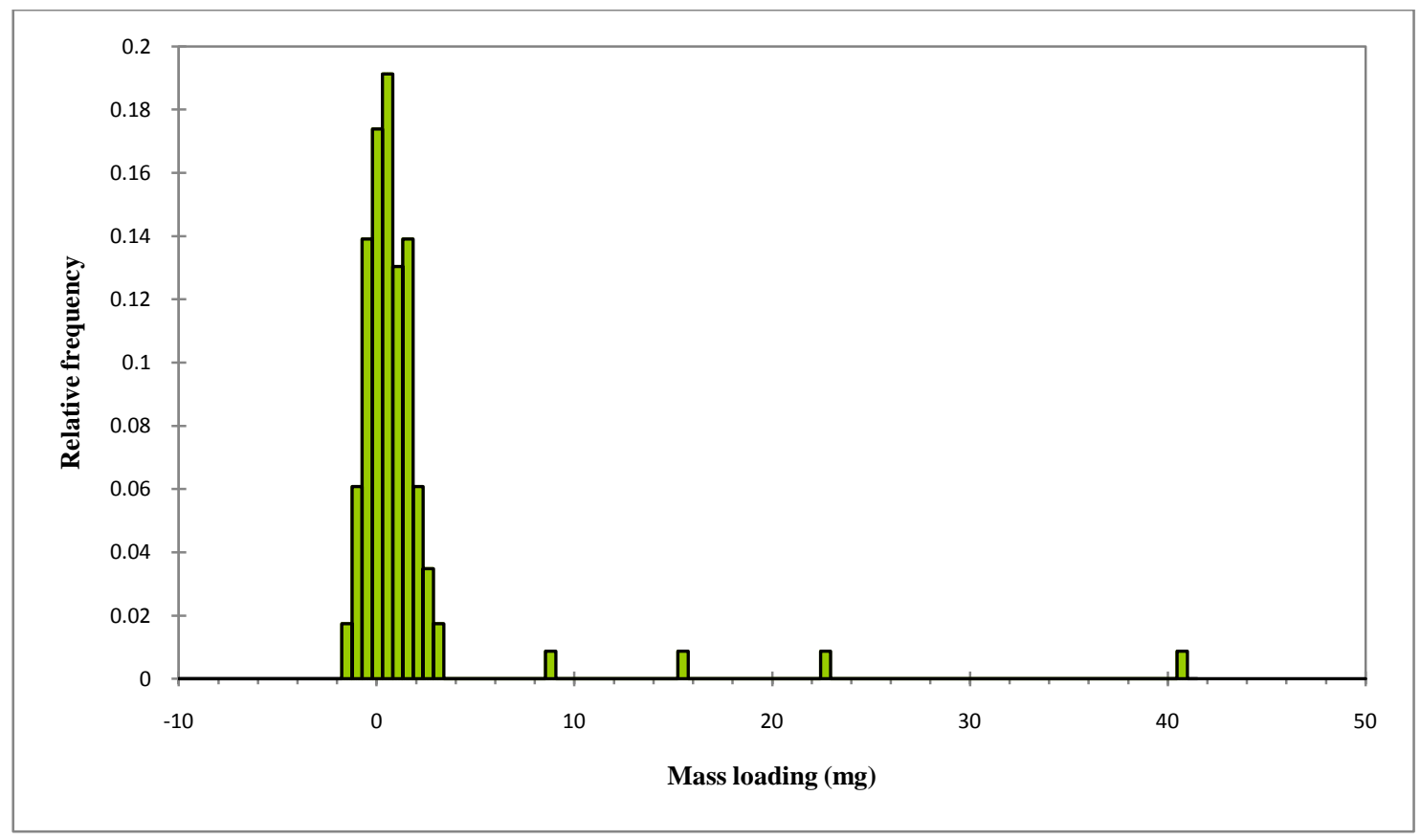

Figure 1: Histogram of Mass Loading in Milligrams Measured on Filters from Sampling Exhaust Stacks

The mass loading mean and standard deviation of all the filters is $0.10 \mathrm{mg} \mathrm{cm}^{-2} \pm 0.35 \mathrm{mg} \mathrm{cm}^{-2}$. Many (28\%) of the mass loading values were negative due to limitations of precision. Since the negative loadings decrease the average loading, omitting them gives a higher, and more conservative, average loading of $0.16 \mathrm{mg} \mathrm{cm}^{-2} \pm 0.40 \mathrm{mg} \mathrm{cm}^{-2}$. Positive mass loadings ranged from 0 to $3.1 \mathrm{mg} \mathrm{cm}^{-2}$. As Figure 1 shows, four values were anomalously high, with three of the mass loading values above $15 \mathrm{mg}$ or $1 \mathrm{mg} \mathrm{cm}^{-2}$, and the fourth highest value being $8.7 \mathrm{mg}$ or 
$0.6 \mathrm{mg} \mathrm{cm}^{-2}$. The largest value is $40.5 \mathrm{mg}$ or $3.07 \mathrm{mg} \mathrm{cm}^{-2}$. All four unusually high values came from the same month and suggest an anomaly. Also, the tare weights of the filters with the two highest loadings were more than two standard deviations below the average filter weight. This means that the gross weights do not need to be unusually high to result in very high mass loadings. The four high loadings are suspect and are considered outliers.

If the negative loadings and the one month of abnormally large loadings are omitted, the mass loading mean and standard deviation is $0.09 \pm 0.06 \mathrm{mg} \mathrm{cm}^{-2}$ and ranges from $0 \mathrm{mg} \mathrm{cm}^{-2}$ to $0.24 \mathrm{mg} \mathrm{cm}^{-2}$. This value of $0.24 \mathrm{mg} \mathrm{cm}^{-2}$ is the assumed upper bound of normal particulate mass loadings that will be used throughout this paper.

\subsection{Activity Counts}

\subsubsection{Sample Filters}

The alpha and beta activity of each of the 116 sample filters was measured. The activity of each of the filters was counted and subsequently converted into a mass of radioactive particles using the following equation.

$$
\text { Radioactive Mass = Measured Activity/Specific Activity }
$$

For alpha particles, the analysts used the specific activity of $0.063 \mathrm{Ci} \mathrm{g}^{-1}$ for ${ }^{239} \mathrm{Pu}$ [Argonne National Laboratory 2005b]. For beta particles, the analysts used the specific activity of $88 \mathrm{Ci} \mathrm{g}^{-1}$ for ${ }^{137}$ Cs [Argonne National Laboratory 2005a]. These are common alpha- and beta/gammaemitting radionuclides from the sampled facilities.

This conversion of activity into mass helped to determine whether radioactive particles play a large role in the mass loading of the filter. The largest total mass of radioactive alpha and beta particles from the 116 filters was $1.9 \times 10^{-8} \mathrm{mg}$, many orders of magnitude below the detection ability of the Mettler-Toledo mass balance. Appendix A contains the full data set.

\subsubsection{Unused Filters}

Analysts also counted the activity of 11 unused filters for this study (see Table 1), converting the background activity into a mass using Equation 1 and the specific activities given above. This yields a background mass-loading average of $1.3 \times 10^{-12} \mathrm{mg} \mathrm{cm}^{-2}$ for the unused filter, with the activity primarily from beta emitters, using the specific activity of ${ }^{137} \mathrm{Cs}$ and a filter area of $13.2 \mathrm{~cm}^{2}$. 
Table 1: Background Activity of Unused Filters

\begin{tabular}{|c|c|c|c|c|c|c|}
\hline Loading & $\begin{array}{c}\text { Alpha, } \\
\text { pCi }\end{array}$ & $\begin{array}{c}\text { Beta, } \\
\text { pCi }\end{array}$ & $\begin{array}{l}\text { Alpha, } \\
\text { mg }\end{array}$ & $\begin{array}{c}\text { Beta, } \\
\text { mg }\end{array}$ & $\begin{array}{l}\text { Alpha, } \\
\text { mg cm }^{-2}\end{array}$ & $\begin{array}{c}\text { Beta, } \\
\text { mg cm}^{-2}\end{array}$ \\
\hline 0 & 0.097 & 1.048 & $1.5 \times 10^{-12}$ & $1.7 \times 10^{-11}$ & $1.2 \times 10^{-13}$ & $1.3 \times 10^{-12}$ \\
\hline 0 & 0.084 & 1.072 & $1.3 \times 10^{-12}$ & $1.7 \times 10^{-11}$ & $1.0 \times 10^{-13}$ & $1.3 \times 10^{-12}$ \\
\hline 0 & 0.087 & 1.078 & $1.4 \times 10^{-12}$ & $1.7 \times 10^{-11}$ & $1.0 \times 10^{-13}$ & $1.3 \times 10^{-12}$ \\
\hline 0 & 0.069 & 1.001 & $1.1 \times 10^{-12}$ & $1.6 \times 10^{-11}$ & $8.3 \times 10^{-14}$ & $1.2 \times 10^{-12}$ \\
\hline 0 & 0.097 & 1.008 & $1.5 \times 10^{-12}$ & $1.6 \times 10^{-11}$ & $1.2 \times 10^{-13}$ & $1.2 \times 10^{-12}$ \\
\hline 0 & 0.059 & 1.027 & $9.4 \times 10^{-13}$ & $1.6 \times 10^{-11}$ & $7.1 \times 10^{-14}$ & $1.2 \times 10^{-12}$ \\
\hline 0 & 0.070 & 1.040 & $1.1 \times 10^{-12}$ & $1.7 \times 10^{-11}$ & $8.4 \times 10^{-14}$ & $1.3 \times 10^{-12}$ \\
\hline 0 & 0.079 & 1.046 & $1.2 \times 10^{-12}$ & $1.7 \times 10^{-11}$ & $9.5 \times 10^{-14}$ & $1.3 \times 10^{-12}$ \\
\hline 0 & 0.098 & 1.012 & $1.5 \times 10^{-12}$ & $1.6 \times 10^{-11}$ & $1.2 \times 10^{-13}$ & $1.2 \times 10^{-12}$ \\
\hline 0 & 0.106 & 1.120 & $1.7 \times 10^{-12}$ & $1.8 \times 10^{-11}$ & $1.3 \times 10^{-13}$ & $1.3 \times 10^{-12}$ \\
\hline 0 & 0.047 & 1.102 & $7.4 \times 10^{-13}$ & $1.7 \times 10^{-11}$ & $5.6 \times 10^{-14}$ & $1.3 \times 10^{-12}$ \\
\hline avg & 0.081 & 1.050 & $1.3 \times 10^{-12}$ & $1.7 \times 10^{-11}$ & $9.7 \times 10^{-14}$ & $1.3 \times 10^{-12}$ \\
\hline st dev & 0.018 & 0.039 & $2.9 \times 10^{-13}$ & $6.2 \times 10^{-13}$ & $2.2 \times 10^{-14}$ & $4.7 \times 10^{-14}$ \\
\hline
\end{tabular}

\subsection{Percent Loss as a Function of Mass Loading}

\subsubsection{Theoretical Rationale}

In order to develop a function relating percent loss to loading of the filter, one must assess the fundamental relationship between the two. A very small amount of material can block the radiation from alpha particles. If a certain thickness of other particles covers the alpha particle, then the radiation will be blocked and not be counted. Higby [1984] calculated that this occurs at a mass distribution of $3.7 \mathrm{mg} \mathrm{cm}^{-2}$ on glass-fiber filters for an alpha particle from ${ }^{239} \mathrm{Pu}$. As the mass loading decreases, less of the radiation from alpha particles is blocked, and a greater percentage of alpha particles will be counted. Luetzelschwab et al. [2000] suggest that when the mass loading is $3.3 \mathrm{mg} \mathrm{cm}^{-2}, 40 \%$ of alpha particles will not be counted, and if mass loading is $2.3 \mathrm{mg} \mathrm{cm}^{-2}, 28 \%$ of alpha particles will not be counted. These values are from calculations of 
absorption curves as a function of absorber thickness for alpha particles using an energy of $5.0 \mathrm{MeV}$. The mass loading in the calculation includes both mass of the front layer of the glassfiber filter (estimated to be $1.3 \mathrm{mg} \mathrm{cm}^{-2}$ ) and mass of the material deposited on the filter. Assuming a standard $1.3 \mathrm{mg} \mathrm{cm}^{-2}$ front filter loading, the data from Luetzelschwab et al. [2000] attribute $28 \%$ and $40 \%$ absorption losses to incremental dust loadings of 1.0 and $2.0 \mathrm{mg} \mathrm{cm}^{-2}$ respectively.

Higby [1984] provides self-absorption data for filters loaded only with radioactive aerosol, considered a light loading. The measured losses of 0 to $24 \%$ (depending on particle size and face velocity) compare well with the calculations by Luetzelschwab et al. [2000] using the thickness of the front filter layer alone.

Visual microscopy provided by Barnett et al. [2009b] demonstrates that the Versapor ${ }^{\circledR} 3000$ membrane filters are surface collectors. That study stated that no particles were observed on the downstream side of the analyzed filters. However, more studies are needed to quantify the burial depth of radioactive particles in the 47 mm diameter, $50 \mu$ m thick Versapor ${ }^{\circledR} 3000$ membrane filters. Data presented by Geryes et al. [2009] show most of the activity depositing in the top layer of a filter, with exponentially less material embedded further down. These experiments had similar face velocities of 1 to $9 \mathrm{~m} \mathrm{~s}^{-1}$ compared to 0.35 to $1.1 \mathrm{~m} \mathrm{~s}^{-1}$ at PNNL but the top layer of the Geryes et al. [2009] filters was $43 \mu \mathrm{m}$ compared to the $50 \mu \mathrm{m}$ full thickness of the Versapor ${ }^{\circledR}$ 3000 membrane filters.

If the assumption that the membrane filters are surface collectors is true, a burial depth of about one tenth the total thickness of the filter might be appropriate. This thickness would be $0.61^{\mathrm{d}} \mathrm{mg} \mathrm{cm}^{-2}$ for the filters used in this study. The value of $1.3 \mathrm{mg} \mathrm{cm}^{-2}$ used by Luetzelschwab et al. [2000] to represent the front filter layer might also be appropriate given the similar size of filters.

Due to the nature of radiation from alpha emitting sources, a logical relationship between percent loss and mass loading would give loss as an exponential function of loading. At low levels of mass loading, there is a small percent loss. Once mass loading reaches a certain value, loss increases exponentially with increasing mass loading until loss is $100 \%$. Another method for determining percent loss given a certain mass loading could be a linear relationship, which appears to be closer to that shown in the absorption curves presented by Luetzelschwab et al. [2000].

\subsubsection{Functions}

\subsubsection{Exponential Using Three Points}

Using the exponential relationship between percent loss and mass loading, the most basic relationship that can be derived comes from the three experimentally-determined points. The study by Luetzelschwab et al. [2000] gives the values of $28 \%$ loss at $2.3 \mathrm{mg} \mathrm{cm}^{-2}$ and $40 \%$ loss at $3.3 \mathrm{mg} \mathrm{cm}^{-2}$ when the front layer of the glass fibers is included in the loading, or $28 \%$ loss at

\footnotetext{
${ }^{\mathrm{d}}$ Dividing the mean tare weight of $0.1054 \mathrm{~g}$ by 10 and allocating that weight over the face of the $47 \mathrm{~mm}$ diameter filter.
} 
$1 \mathrm{mg} \mathrm{cm}^{-2}$ and $40 \%$ loss at $2 \mathrm{mg} \mathrm{cm}^{-2}$ with dust loading alone. Higby’s study gives the value of $100 \%$ loss at a thickness of $3.7 \mathrm{mg} \mathrm{cm}^{-2}$. Figure 2 and Equation 2 below represent the best fit exponential equation and graph of these three data points using dust loading alone.

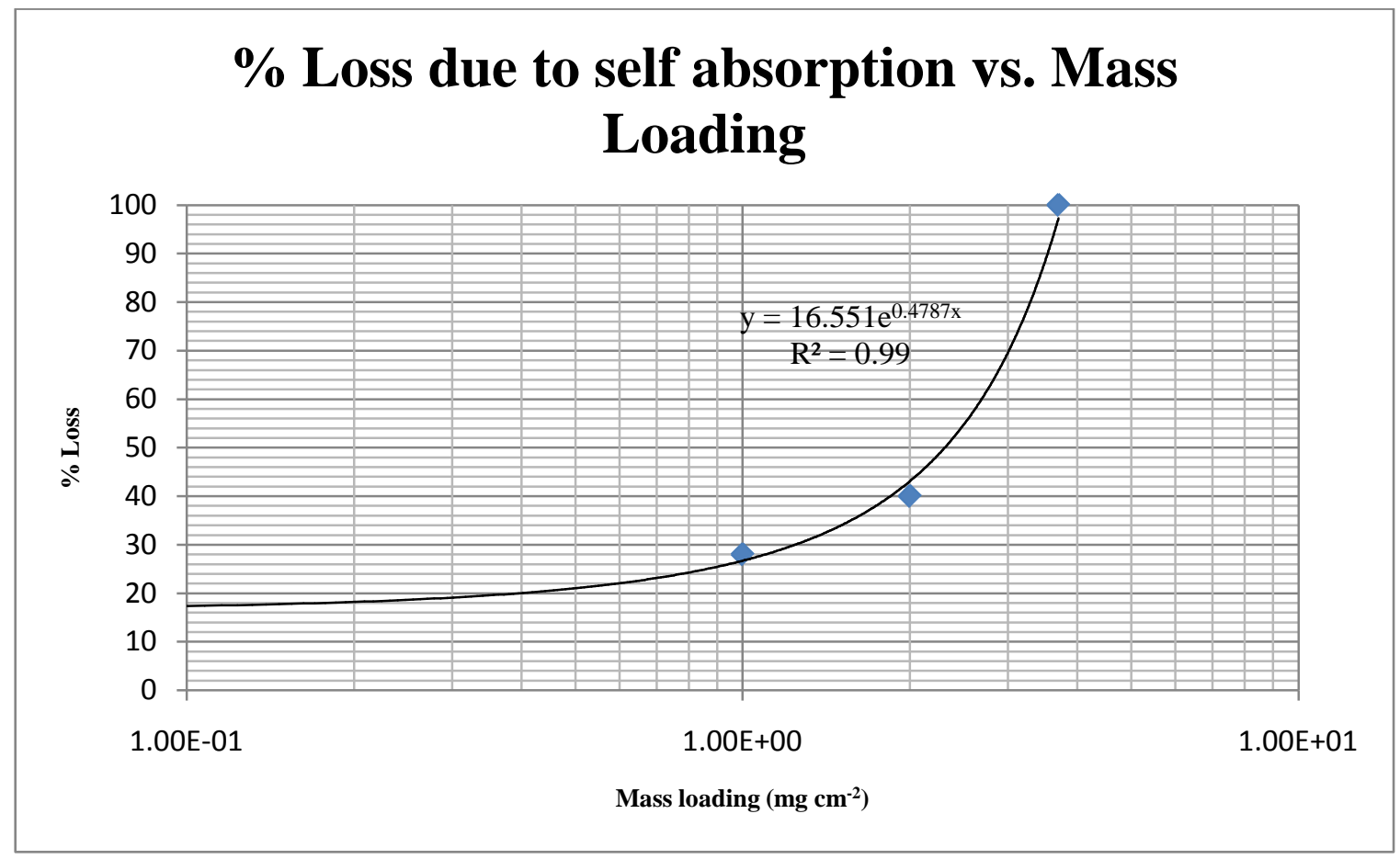

Figure 2: Exponential Relationship of Known Values

$$
\% \text { Loss }=16.6 \mathrm{e}^{0.48^{*} \text { Loading }}
$$

Equation 2 requires a loading value with units of $\mathrm{mg} \mathrm{cm}^{-2}$ that does not include the front filter loading; in effect, it assumes a front filter loading of $1.3 \mathrm{mg} \mathrm{cm}^{-2}$ as given by Luetzelschwab et al [2000]. The equation fits the three data points with a coefficient of determination $\left(R^{2}\right)$ of 0.99 ; it does not assume zero losses with no loading (e.g., new unused filters for background determinations). Using this equation, the expected percent loss for PNNL filters with average loadings of $0.1 \mathrm{mg} \mathrm{cm}^{-2}$ are $17 \%$ and loadings up to $0.24 \mathrm{mg} \mathrm{cm}^{-2}$ are $19 \%$. Using this exponential function, as loadings trend toward zero, the percent loss trends towards just under $17 \%$.

\subsubsection{Linear Relationship}

The same data points used to evaluate the exponential relationship can be used to consider a linear relationship. In addition, a membrane filter with zero loading will theoretically have zero loss and thus the intercept can be forced to zero for a fourth data point. Figure 3 exhibits this method with the resulting equation and regression coefficient. 


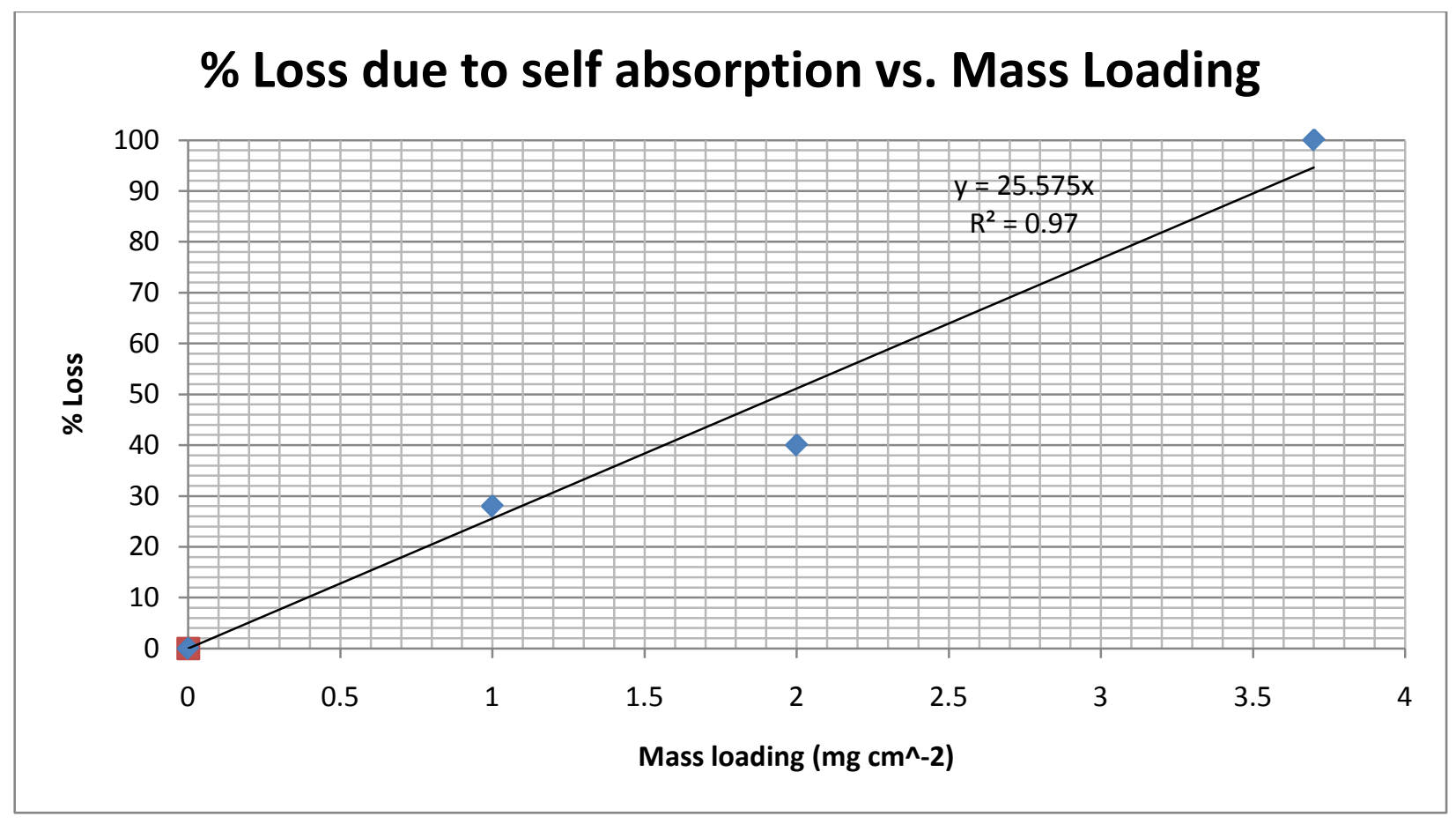

Figure 3: Linear Relationship of Known Values

$\%$ Loss $=25.6 *$ Loading

Equation 3 requires a loading value with units of $\mathrm{mg}^{\mathrm{cm}-2}$ that does not include the front filter loading. Losses for an average light filter loading (dust loading alone) of $0.1 \mathrm{mg} \mathrm{cm}^{-2}$ are $2.6 \%$ and $6 \%$ loss for a loading of $0.24 \mathrm{mg} \mathrm{cm}^{-2}$. The coefficient of determination for the linear relationship is 0.97 .

\subsubsection{Assessment of Percent Loss Values}

EM staff utilized two different methods of developing equations that relate percent loss to the mass loading of a filter, and also determined the range of typical and atypical mass loading values at PNNL facilities. The upper bound of the typical particulate mass loading values is $0.24 \mathrm{mg} \mathrm{cm}^{-2}$, and the upper bound of the atypical mass loading values is $3.07 \mathrm{mg} \mathrm{cm}^{-2}$. Table 2 gives the percent loss at the typical upper bound as calculated from the different equations.

Table 3 gives the percent loss at the atypical mass loadings as calculated from the different equations. 
Table 2: Percent Loss at Typical Average and Upper Bound Mass Loadings

\begin{tabular}{|c|c|c|}
\hline Equation & Mass loading $\left(\mathrm{mg} \mathrm{cm}^{-2}\right)$ & \% Loss \\
\hline 2 & 0.09 & 17.3 \\
\hline 3 & 0.09 & 2.3 \\
\hline 2 & 0.24 & 18.6 \\
\hline 3 & 0.24 & 6.1 \\
\hline
\end{tabular}

Table 3: Percent Loss at Atypical Mass Loadings

\begin{tabular}{|c|c|c|c|}
\hline Equation & Filter ID & Mass loading $\left(\mathrm{mg} \mathrm{cm}^{-2}\right)$ & $\%$ Loss \\
\hline 2 & $09-1828$ & 0.66 & 23 \\
\hline 3 & $09-1828$ & 0.66 & 17 \\
\hline \multicolumn{5}{|l}{} & 29 \\
\hline 2 & $09-1877$ & 1.19 & 30 \\
\hline 3 & $09-1877$ & 1.19 & 38 \\
\hline 2 & $09-1878$ & 1.71 & 44 \\
\hline 3 & $09-1878$ & 1.71 & 72 \\
\hline 2 & $09-1829$ & 3.07 & 79 \\
\hline 3 & $09-1829$ & 3.07 & \\
\hline \multicolumn{5}{|l|}{} \\
\hline
\end{tabular}

\subsection{Visual Inspection}

In order to see whether unusually high loadings could easily be observed, analysts observed and recorded the color of the filter after sample collection for each of the 116 filters analyzed. If the filters with high mass loadings were easily identified by a darker color, these filters could be analyzed separately by acid-digesting the filter to recover all radioactive particles, as was done in the study by Barnett et al. [2009b]. If the highly-loaded filters could be readily identified, there would be no need to record the tare weight of every filter prior to installation in order to measure 
the mass loading. Highly-loaded filters could simply be removed and analyzed separately. Unfortunately, the visual observations did not sufficiently identify filters with unusually high mass loading. Appendix A presents the observations showing this lack of correlation between mass loading and dark color observations.

\subsection{Conclusions}

Under normal operating conditions at the stacks monitored by EM, the mass loading of sample filters averages $0.09 \pm 0.12(2 \sigma) \mathrm{mg} \mathrm{cm}^{-2}$ (removing negative values and outliers) and ranges from $0 \mathrm{mg} \mathrm{cm}^{-2}$ to $0.24 \mathrm{mg} \mathrm{cm}^{-2}$. This study presents two different methods of relating percent loss due to self-absorption to filter mass loading: exponential and linear relationships based on data from Luetzelschwab et al. [2000] and Higby [1984]. These methods resulted in approximate 6\% and $19 \%$ loss using the linear and exponential relationship respectively at the maximum typical mass loading as seen in Table 2. ANSI/HPS N13.1-1999, Sampling and Monitoring Releases of Airborne Radioactive Substances from the Stack and Ducts of Nuclear Facilities, recommends that if penetration of radioactive material into the collection media or self-absorption of radiation by the material collected would reduce the count rate by more than $5 \%$, a correction factor should be used. Therefore, the correction factor of 0.85 remains conservative.

For higher accuracy, each filter may be weighed before and after installation on the sampling system. Thus, having tare weights and gross weights allows the user to determine the mass loading of each filter and apply any applicable correction factor on a case-by-case basis. 


\section{References}

American National Standards Institute. 1999. Sampling and Monitoring Releases of Airborne Radioactive Substances From the Stacks and Ducts of Nuclear Facilities. Health Physics Society, ANSI/HPS N13.1-1999, McLean, Virginia.

Barnett JM and JE Kane II. 1993. Flow Rate Through a Filter with a 25-mm Diameter Aperture for Hanford Site Alpha Continuous Air Monitors. Radiation Protection Management: 10(4):41-46.

Barnett JM, VI Cullinan, DS Barnett, TLT Trang-Le, M Bliss, LR Greenwood and MY Ballinger. 2009a. Results of a Self-Absorption Study on the Versapor 3000 47-mm Filters for Radioactive Particulate Air Stack Sampling. Health Physics: 97(5):S161-S168

Barnett JM, VI Cullinan, DS Barnett, TLT Trang-Le, M Bliss, LR Greenwood and MY Ballinger. 2009b. Results of Self-Absorption Study on the Versapor 3000 Filters for Radioactive Particulate Air Sampling. Pacific Northwest National Laboratory, PNNL-SA-62011, Rev 1, Richland, Washington.

Geryes T, C Monsanglant-Louvet, L Berger and E Gehin. 2009. Application of the Monte Carlo Method to Study the Alpha Particle Energy Spectra for Radioactive Aerosol Sampled by an Air Filer. Health Physics: 97(2):125-131.

Higby DP. 1984. Effects of Particle Size and Velocity on Burial Depth of Airborne Particles in Glass Fiber Filters. Pacific Northwest Laboratory, PNL-5278, Richland, Washington.

Argonne National Laboratory. 2005a. Cesium. Argonne National Laboratory, Environmental Science Division (EVS), Human Health Fact Sheet, August 2005, Argonne, Illinois. Available at: $\quad$ www.evs.anl.gov/pub/doc/Cesium.pdf. Accessed 29 November 2010.

Argonne National Laboratory. 2005b. Plutonium. Argonne National Laboratory, EVS, Human Health Fact Sheet, August 2005, Argonne, Illinois. Available at: www.evs.anl.gov/pub/doc/Plutonium.pdf. Accessed 29 November 2010.

Luetzelschwab JW, C Storey, K Zraly, and D Dussinger. 2000. "Self-absorption of Alpha and Beta Particles in a Fiberglass Filter.” Health Physics: 79(4):425-430. 
Appendix A: Raw Filter Data

\begin{tabular}{|c|c|c|c|c|c|c|c|c|c|c|c|}
\hline Filter ID & $\begin{array}{c}\text { Alpha } \\
\text { RPTD } \\
\text { (pCi) }\end{array}$ & $\begin{array}{c}\text { Beta } \\
\text { RPTD } \\
\text { (pCi) }\end{array}$ & $\begin{array}{c}\text { Alpha } \\
\text { Mass (mg) }\end{array}$ & $\begin{array}{c}\text { Beta Mass } \\
\text { (mg) }\end{array}$ & $\begin{array}{l}\text { Tare } \\
\text { Wt. } \\
\text { (mg) }\end{array}$ & $\begin{array}{c}\text { Tare Date } \\
\text { Wt. }\end{array}$ & $\begin{array}{c}\text { Gross } \\
\text { Wt. } \\
\text { (mg) }\end{array}$ & $\begin{array}{c}\text { Gross Date } \\
\text { Wt. }\end{array}$ & $\begin{array}{c}\text { Mass } \\
\text { Loading } \\
\text { (mg) }\end{array}$ & Comments & $\begin{array}{l}\text { Loading } \\
\left(\mathrm{mg} \mathrm{cm}^{-2}\right)\end{array}$ \\
\hline $10-0101$ & 0.3148 & 0.3230 & $1.852 \mathrm{E}-11$ & $3.671 \mathrm{E}-12$ & 107.8 & $11 / 10 / 2009$ & 106.4 & $12 / 9 / 2009$ & -1.4 & Light Dust & -0.1061 \\
\hline $10-0099$ & 0.0689 & 0.0795 & $4.050 \mathrm{E}-12$ & $9.039 \mathrm{E}-13$ & 103.5 & $11 / 10 / 2009$ & 102.1 & $12 / 9 / 2009$ & -1.4 & Light Dust & -0.1061 \\
\hline $10-0103$ & 0.1918 & -0.0828 & $1.128 \mathrm{E}-11$ & $-9.407 \mathrm{E}-13$ & 108.9 & $11 / 10 / 2009$ & 107.6 & $12 / 9 / 2009$ & -1.3 & Light Dust & -0.0985 \\
\hline 09-1098 & -0.0437 & 0.3186 & $-2.570 \mathrm{E}-12$ & $3.620 \mathrm{E}-12$ & 113.3 & 2/18/2009 & 112.1 & $3 / 4 / 2009$ & -1.2 & Light Brown & -0.0909 \\
\hline $10-0100$ & 0.1642 & 0.3991 & $9.661 \mathrm{E}-12$ & $4.535 \mathrm{E}-12$ & 100.3 & $11 / 10 / 2009$ & 99.2 & $12 / 9 / 2009$ & -1.1 & Light Dust & -0.0833 \\
\hline 09-1099 & -0.0757 & -0.0472 & $-4.451 \mathrm{E}-12$ & $-5.363 \mathrm{E}-13$ & 107.5 & $2 / 18 / 2009$ & 106.4 & $3 / 4 / 2009$ & $\begin{array}{l}-1.1 \\
\end{array}$ & Light Brown & -0.0833 \\
\hline $09-2741$ & 0.0443 & 1.1843 & $2.604 \mathrm{E}-12$ & $1.346 \mathrm{E}-11$ & 102.4 & 9/16/2009 & 101.4 & 9/30/2009 & -1.0 & Light Dust & -0.0758 \\
\hline $09-2740$ & -0.0700 & 0.0109 & $-4.120 \mathrm{E}-12$ & $1.235 \mathrm{E}-13$ & 104.4 & $9 / 16 / 2009$ & 103.4 & 9/30/2009 & -1.0 & Light Dust & -0.0758 \\
\hline $09-1930$ & -0.0773 & 0.0559 & $-4.546 \mathrm{E}-12$ & $6.353 \mathrm{E}-13$ & 123.4 & $4 / 29 / 2009$ & 122.6 & $5 / 19 / 2009$ & $\begin{array}{l}-0.8 \\
\end{array}$ & Light color & -0.0606 \\
\hline $10-0096$ & -0.0364 & 5.0378 & $-2.142 \mathrm{E}-12$ & 5.725E-11 & 113.4 & $11 / 10 / 2009$ & 112.6 & $12 / 9 / 2009$ & -0.8 & Dark Dust & -0.0606 \\
\hline $10-0686$ & 0.0193 & 0.0357 & $1.137 \mathrm{E}-12$ & $4.059 \mathrm{E}-13$ & 103.7 & $5 / 26 / 2010$ & 103.0 & $6 / 9 / 2010$ & -0.7 & Very Light & -0.0530 \\
\hline $10-0158$ & -0.0894 & 0.2562 & $-5.257 \mathrm{E}-12$ & 2.912E-12 & 112.7 & $12 / 23 / 2009$ & 112.0 & $1 / 6 / 2010$ & -0.7 & $\begin{array}{l}\text { Very Light } \\
\text { Brown }\end{array}$ & -0.0530 \\
\hline $10-0346$ & -0.0558 & 0.5841 & $-3.284 \mathrm{E}-12$ & 6.637E-12 & 101.2 & $2 / 2 / 2010$ & 100.6 & $2 / 17 / 2010$ & -0.6 & Light & -0.0455 \\
\hline $09-1075$ & 0.0531 & 0.1227 & $3.126 \mathrm{E}-12$ & $1.394 \mathrm{E}-12$ & 103.4 & $2 / 4 / 2009$ & 102.9 & $2 / 25 / 2009$ & -0.5 & Light Brown & -0.0379 \\
\hline $09-1550$ & 0.0604 & -0.3152 & $3.552 \mathrm{E}-12$ & $-3.582 \mathrm{E}-12$ & 100.7 & $3 / 3 / 2009$ & 100.2 & $3 / 24 / 2009$ & -0.5 & Light Brown & -0.0379 \\
\hline
\end{tabular}




\begin{tabular}{|c|c|c|c|c|c|c|c|c|c|c|c|}
\hline Filter ID & $\begin{array}{c}\text { Alpha } \\
\text { RPTD } \\
\text { (pCi) }\end{array}$ & $\begin{array}{c}\text { Beta } \\
\text { RPTD } \\
\text { (pCi) }\end{array}$ & $\begin{array}{c}\text { Alpha } \\
\text { Mass (mg) }\end{array}$ & $\begin{array}{c}\text { Beta Mass } \\
\text { (mg) }\end{array}$ & $\begin{array}{l}\text { Tare } \\
\text { Wt. } \\
\text { (mg) }\end{array}$ & $\begin{array}{c}\text { Tare Date } \\
\text { Wt. }\end{array}$ & $\begin{array}{c}\text { Gross } \\
\text { Wt. } \\
\text { (mg) }\end{array}$ & $\begin{array}{c}\text { Gross Date } \\
\text { Wt. }\end{array}$ & $\begin{array}{c}\text { Mass } \\
\text { Loading } \\
\text { (mg) }\end{array}$ & Comments & $\begin{array}{c}\text { Loading } \\
\left(\mathrm{mg} \mathrm{cm}^{-2}\right)\end{array}$ \\
\hline $10-0102$ & 0.1642 & 0.3991 & $9.661 \mathrm{E}-12$ & $4.535 \mathrm{E}-12$ & 95.1 & 11/10/2009 & 94.6 & $12 / 9 / 2009$ & -0.5 & Light Dust & -0.0379 \\
\hline $09-2642$ & -0.0787 & 0.6152 & $-4.629 \mathrm{E}-12$ & $6.991 \mathrm{E}-12$ & 106.7 & $8 / 11 / 2009$ & 106.2 & $9 / 8 / 2009$ & -0.5 & Light Dust & -0.0379 \\
\hline $10-0110$ & -0.0713 & 0.0747 & $-4.195 \mathrm{E}-12$ & $8.485 \mathrm{E}-13$ & 106.3 & $11 / 24 / 2009$ & 105.9 & $1 / 7 / 2010$ & -0.4 & Light Grey & -0.0303 \\
\hline $10-0373$ & 0.1715 & 0.1242 & $1.009 \mathrm{E}-11$ & $1.412 \mathrm{E}-12$ & 112.7 & $2 / 17 / 2010$ & 112.3 & $3 / 4 / 2010$ & -0.4 & Light Dust & -0.0303 \\
\hline 09-1072 & -0.0738 & 0.0925 & $-4.340 \mathrm{E}-12$ & $1.051 \mathrm{E}-12$ & 101.7 & $2 / 11 / 2009$ & 101.3 & $2 / 25 / 2009$ & -0.4 & Light Brown & -0.0303 \\
\hline 10-0109 & -0.0797 & 0.0947 & $-4.688 \mathrm{E}-12$ & $1.076 \mathrm{E}-12$ & 103.6 & $11 / 24 / 2009$ & 103.2 & $1 / 7 / 2010$ & -0.4 & Light Grey & -0.0303 \\
\hline $10-0397$ & -0.0821 & -0.0435 & $-4.830 \mathrm{E}-12$ & $-4.941 \mathrm{E}-13$ & 100.8 & $3 / 3 / 2010$ & 100.4 & $3 / 24 / 2010$ & -0.4 & Light Dust & -0.0303 \\
\hline $10-0687$ & -0.0713 & 0.0341 & $-4.195 \mathrm{E}-12$ & $3.871 \mathrm{E}-13$ & 99.1 & $5 / 26 / 2010$ & 98.7 & $6 / 9 / 2010$ & -0.4 & Very Light & -0.0303 \\
\hline $10-0398$ & 0.1918 & 0.1622 & $1.128 \mathrm{E}-11$ & $1.844 \mathrm{E}-12$ & 105.6 & $3 / 3 / 2010$ & 105.3 & $3 / 24 / 2010$ & -0.3 & Light Dust & -0.0227 \\
\hline $10-0086$ & -0.0942 & -0.0342 & $-5.541 \mathrm{E}-12$ & $-3.882 \mathrm{E}-13$ & 111.2 & $10 / 28 / 2009$ & 110.9 & $11 / 17 / 2009$ & -0.3 & Light Dust & -0.0227 \\
\hline $10-0159$ & -0.0566 & 0.2824 & $-3.327 \mathrm{E}-12$ & $3.210 \mathrm{E}-12$ & 102.0 & $12 / 23 / 2009$ & 101.7 & $1 / 6 / 2010$ & -0.3 & $\begin{array}{c}\text { Very Light } \\
\text { Brown }\end{array}$ & -0.0227 \\
\hline $10-0347$ & 0.0689 & 0.2042 & $4.054 \mathrm{E}-12$ & $2.320 \mathrm{E}-12$ & 109.3 & $2 / 2 / 2010$ & 109.1 & $2 / 17 / 2010$ & -0.2 & Light & -0.0152 \\
\hline $10-0087$ & -0.0615 & -0.1525 & $-3.616 \mathrm{E}-12$ & $-1.733 \mathrm{E}-12$ & 115.2 & $10 / 28 / 2009$ & 115.0 & $11 / 17 / 2009$ & -0.2 & Light Dust & -0.0152 \\
\hline $10-0507$ & 0.4106 & 0.2826 & $2.415 \mathrm{E}-11$ & $3.212 \mathrm{E}-12$ & 101.2 & $3 / 9 / 2010$ & 101.1 & $4 / 7 / 2010$ & -0.1 & Tan & -0.0076 \\
\hline $10-0328$ & -0.0559 & 0.0128 & $-3.285 \mathrm{E}-12$ & $1.455 \mathrm{E}-13$ & 114.5 & $1 / 6 / 2010$ & 114.4 & $2 / 4 / 2010$ & -0.1 & Light & -0.0076 \\
\hline $10-0097$ & 0.6126 & 1.0383 & 3.604E-11 & $1.180 \mathrm{E}-11$ & 106.4 & $11 / 10 / 2009$ & 106.3 & $12 / 9 / 2009$ & -0.1 & Dark Dust & -0.0076 \\
\hline $09-2644$ & -0.0787 & -0.2776 & $-4.629 \mathrm{E}-12$ & $-3.154 \mathrm{E}-12$ & 131.4 & $8 / 11 / 2009$ & 131.3 & $9 / 8 / 2009$ & -0.1 & Medium Dust & -0.0076 \\
\hline
\end{tabular}




\begin{tabular}{|c|c|c|c|c|c|c|c|c|c|c|c|}
\hline Filter ID & $\begin{array}{c}\text { Alpha } \\
\text { RPTD } \\
\text { (pCi) }\end{array}$ & $\begin{array}{c}\text { Beta } \\
\text { RPTD } \\
\text { (pCi) }\end{array}$ & $\begin{array}{c}\text { Alpha } \\
\text { Mass (mg) }\end{array}$ & $\begin{array}{c}\text { Beta Mass } \\
\text { (mg) }\end{array}$ & $\begin{array}{l}\text { Tare } \\
\text { Wt. } \\
\text { (mg) }\end{array}$ & $\begin{array}{c}\text { Tare Date } \\
\text { Wt. }\end{array}$ & $\begin{array}{c}\text { Gross } \\
\text { Wt. } \\
\text { (mg) }\end{array}$ & $\begin{array}{c}\text { Gross Date } \\
\text { Wt. }\end{array}$ & $\begin{array}{c}\text { Mass } \\
\text { Loading } \\
\text { (mg) }\end{array}$ & Comments & $\begin{array}{c}\text { Loading } \\
\left(\mathrm{mg} \mathrm{cm}^{-2}\right)\end{array}$ \\
\hline $09-2094$ & -0.0689 & 0.1623 & $-4.054 \mathrm{E}-12$ & $1.845 \mathrm{E}-12$ & 95.2 & 6/24/2009 & 95.2 & $7 / 8 / 2009$ & 0.0 & LW & 0.0000 \\
\hline 09-2093 & -0.1111 & 0.3914 & $-6.535 E-12$ & $4.448 \mathrm{E}-12$ & 112.0 & 6/24/2009 & 112.0 & $7 / 8 / 2009$ & 0.0 & LW & 0.0000 \\
\hline $10-0098$ & 0.4058 & 4.8250 & $2.387 \mathrm{E}-11$ & 5.483E-11 & 105.8 & 11/10/2009 & 105.8 & 12/9/2009 & 0.0 & Dark Dust & 0.0000 \\
\hline $10-0374$ & 0.0762 & 0.3017 & $4.484 \mathrm{E}-12$ & $3.429 \mathrm{E}-12$ & 107.3 & $2 / 17 / 2010$ & 107.3 & $3 / 4 / 2010$ & 0.0 & Light Dust & 0.0000 \\
\hline $10-0072$ & -0.0942 & 0.2516 & $-5.541 \mathrm{E}-12$ & $2.859 \mathrm{E}-12$ & 105.3 & $10 / 14 / 2009$ & 105.4 & $10 / 29 / 2009$ & 0.1 & Light Dust & 0.0076 \\
\hline $09-1074$ & 0.0268 & 0.2539 & $1.579 \mathrm{E}-12$ & $2.885 \mathrm{E}-12$ & 109.0 & $2 / 11 / 2009$ & 109.1 & $2 / 25 / 2009$ & 0.1 & Light Brown & 0.0076 \\
\hline $09-2687$ & 0.0836 & 0.1411 & $4.918 \mathrm{E}-12$ & $1.604 \mathrm{E}-12$ & 92.6 & $9 / 2 / 2009$ & 92.7 & 9/16/2009 & 0.1 & Light Dust & 0.0076 \\
\hline $09-2643$ & -0.1183 & 1.1135 & $-6.962 \mathrm{E}-12$ & $1.265 \mathrm{E}-11$ & 109.9 & $8 / 11 / 2009$ & 110.0 & $9 / 8 / 2009$ & 0.1 & Medium Dust & 0.0076 \\
\hline $10-0544$ & -0.0966 & 0.2718 & $-5.683 \mathrm{E}-12$ & $3.088 \mathrm{E}-12$ & 107.5 & $3 / 31 / 2010$ & 107.6 & $4 / 15 / 2010$ & 0.1 & Light Brown & 0.0076 \\
\hline 09-1079 & 0.0492 & -0.3537 & $2.893 \mathrm{E}-12$ & $-4.019 \mathrm{E}-12$ & 100.3 & $2 / 10 / 2009$ & 100.5 & $2 / 25 / 2009$ & 0.2 & Light Brown & 0.0152 \\
\hline 09-1931 & 0.1918 & 0.3731 & $1.128 \mathrm{E}-11$ & $4.240 \mathrm{E}-12$ & 120.7 & 4/29/2009 & 121.0 & 5/19/2009 & 0.3 & Brown color & 0.0227 \\
\hline $09-2639$ & 0.2233 & 2.4556 & $1.314 \mathrm{E}-11$ & $2.791 \mathrm{E}-11$ & 97.4 & $8 / 11 / 2009$ & 97.7 & $9 / 8 / 2009$ & 0.3 & Dark Dust & 0.0227 \\
\hline $09-1730$ & -0.0942 & -0.1817 & $-5.541 \mathrm{E}-12$ & $-2.065 \mathrm{E}-12$ & 93.0 & $3 / 18 / 2009$ & 93.3 & $4 / 1 / 2009$ & 0.3 & Light Brown & 0.0227 \\
\hline 09-1076 & 0.0615 & 0.9231 & $3.616 \mathrm{E}-12$ & $1.049 \mathrm{E}-11$ & 106.5 & $2 / 4 / 2009$ & 106.8 & $2 / 25 / 2009$ & 0.3 & Dark Brown & 0.0227 \\
\hline $10-0073$ & 0.0762 & -0.2206 & $4.484 \mathrm{E}-12$ & $-2.507 \mathrm{E}-12$ & 99.7 & $10 / 14 / 2009$ & 100.0 & $10 / 29 / 2009$ & 0.3 & Light Dust & 0.0227 \\
\hline $10-0329$ & 0.0591 & 0.1769 & $3.475 \mathrm{E}-12$ & $2.011 \mathrm{E}-12$ & 106.9 & $1 / 6 / 2010$ & 107.2 & $2 / 4 / 2010$ & 0.3 & Light & 0.0227 \\
\hline $10-0407$ & -0.0749 & 0.1972 & $-4.404 \mathrm{E}-12$ & $2.241 \mathrm{E}-12$ & 104.9 & $3 / 9 / 2010$ & 105.2 & $4 / 7 / 2010$ & 0.3 & Light Dust & 0.0227 \\
\hline 09-1073 & 0.0583 & 0.7764 & $3.427 \mathrm{E}-12$ & 8.823E-12 & 110.2 & $2 / 11 / 2009$ & 110.6 & $2 / 25 / 2009$ & 0.4 & Light Brown & 0.0303 \\
\hline
\end{tabular}




\begin{tabular}{|c|c|c|c|c|c|c|c|c|c|c|c|}
\hline Filter ID & $\begin{array}{c}\text { Alpha } \\
\text { RPTD } \\
\text { (pCi) }\end{array}$ & $\begin{array}{c}\text { Beta } \\
\text { RPTD } \\
\text { (pCi) }\end{array}$ & $\begin{array}{c}\text { Alpha } \\
\text { Mass (mg) }\end{array}$ & $\begin{array}{c}\text { Beta Mass } \\
\text { (mg) }\end{array}$ & $\begin{array}{l}\text { Tare } \\
\text { Wt. } \\
\text { (mg) }\end{array}$ & $\begin{array}{c}\text { Tare Date } \\
\text { Wt. }\end{array}$ & $\begin{array}{c}\text { Gross } \\
\text { Wt. } \\
\text { (mg) }\end{array}$ & $\begin{array}{c}\text { Gross Date } \\
\text { Wt. }\end{array}$ & $\begin{array}{c}\text { Mass } \\
\text { Loading } \\
\text { (mg) }\end{array}$ & Comments & $\begin{array}{c}\text { Loading } \\
\left(\mathrm{mg} \mathrm{cm}^{-2}\right)\end{array}$ \\
\hline $10-0408$ & 0.0344 & 0.0908 & $2.025 \mathrm{E}-12$ & $1.032 \mathrm{E}-12$ & 97.9 & $3 / 9 / 2010$ & 98.3 & $4 / 7 / 2010$ & 0.4 & Tan & 0.0303 \\
\hline 09-1731 & -0.0566 & -0.3034 & $-3.327 \mathrm{E}-12$ & $-3.447 \mathrm{E}-12$ & 105.8 & 3/18/2009 & 106.2 & $4 / 1 / 2009$ & 0.4 & Light Brown & 0.0303 \\
\hline $09-2050$ & -0.1014 & 0.3059 & $-5.967 \mathrm{E}-12$ & $3.476 \mathrm{E}-12$ & 102.0 & 6/9/2009 & 102.4 & 6/24/2009 & 0.4 & LW & 0.0303 \\
\hline $09-1077$ & -0.0659 & 3.5170 & $-3.876 \mathrm{E}-12$ & 3.997E-11 & 112.2 & $2 / 10 / 2009$ & 112.7 & $2 / 25 / 2009$ & 0.5 & Dark Brown & 0.0379 \\
\hline $10-0215$ & 0.1746 & 1.8619 & $1.027 \mathrm{E}-11$ & $2.116 \mathrm{E}-11$ & 112.1 & $1 / 6 / 2010$ & 112.7 & $1 / 27 / 2010$ & 0.6 & Pale grey & 0.0455 \\
\hline $09-1551$ & 0.0812 & 1.1875 & $4.774 \mathrm{E}-12$ & $1.349 \mathrm{E}-11$ & 104.0 & $3 / 3 / 2009$ & 104.6 & $3 / 24 / 2009$ & 0.6 & Light Brown & 0.0455 \\
\hline $09-2008$ & 0.0556 & 1.0544 & $3.268 \mathrm{E}-12$ & $1.198 \mathrm{E}-11$ & 102.6 & $5 / 27 / 2009$ & 103.2 & $6 / 10 / 2009$ & 0.6 & Brown color & 0.0455 \\
\hline $09-2716$ & 0.1691 & 0.8308 & $9.945 \mathrm{E}-12$ & $9.441 \mathrm{E}-12$ & 100.3 & $8 / 25 / 2009$ & 100.9 & 9/18/2009 & 0.6 & Light Dust & 0.0455 \\
\hline $09-2686$ & 0.1594 & 0.0016 & $9.377 \mathrm{E}-12$ & $1.765 \mathrm{E}-14$ & 93.3 & $9 / 2 / 2009$ & 93.9 & 9/16/2009 & 0.6 & Light Dust & 0.0455 \\
\hline $10-0059$ & 0.1618 & 0.1398 & $9.519 \mathrm{E}-12$ & $1.588 \mathrm{E}-12$ & 105.0 & 9/30/2009 & 105.6 & $10 / 15 / 2009$ & 0.6 & Light Dust & 0.0455 \\
\hline $10-0214$ & 0.0411 & -0.1491 & $2.415 \mathrm{E}-12$ & $-1.694 \mathrm{E}-12$ & 116.8 & $1 / 6 / 2010$ & 117.4 & $1 / 27 / 2010$ & 0.6 & Pale very grey & 0.0455 \\
\hline $10-0545$ & -0.0836 & -0.0990 & $-4.918 \mathrm{E}-12$ & $-1.125 \mathrm{E}-12$ & 99.7 & $3 / 31 / 2010$ & 100.3 & $4 / 15 / 2010$ & 0.6 & Light Brown & 0.0455 \\
\hline $09-2007$ & 0.0317 & 0.0016 & $1.866 \mathrm{E}-12$ & $1.849 \mathrm{E}-14$ & 107.3 & $5 / 27 / 2009$ & 108.0 & $6 / 10 / 2009$ & 0.7 & Light color & 0.0530 \\
\hline $10-0060$ & 0.0443 & 0.1671 & $2.604 \mathrm{E}-12$ & $1.899 \mathrm{E}-12$ & 104.3 & 9/30/2009 & 105.0 & $10 / 15 / 2009$ & 0.7 & Light Dust & 0.0530 \\
\hline $09-2049$ & 0.1489 & 0.0456 & $8.758 \mathrm{E}-12$ & $5.178 \mathrm{E}-13$ & 113.6 & $6 / 9 / 2009$ & 114.3 & $6 / 24 / 2009$ & 0.7 & LW & 0.0530 \\
\hline $09-2587$ & 0.0342 & 0.0863 & $2.010 \mathrm{E}-12$ & $9.802 \mathrm{E}-13$ & 100.3 & $8 / 5 / 2009$ & 101.0 & $8 / 25 / 2009$ & 0.7 & Light Dust & 0.0530 \\
\hline $10-0134$ & 0.1648 & 0.2922 & $9.692 \mathrm{E}-12$ & 3.320E-12 & 106.0 & $12 / 10 / 2009$ & 106.7 & $12 / 29 / 2009$ & 0.7 & $\begin{array}{c}\text { Very Light } \\
\text { Brown }\end{array}$ & 0.0530 \\
\hline
\end{tabular}




\begin{tabular}{|c|c|c|c|c|c|c|c|c|c|c|c|}
\hline Filter ID & $\begin{array}{c}\text { Alpha } \\
\text { RPTD } \\
\text { (pCi) }\end{array}$ & $\begin{array}{c}\text { Beta } \\
\text { RPTD } \\
\text { (pCi) }\end{array}$ & $\begin{array}{c}\text { Alpha } \\
\text { Mass (mg) }\end{array}$ & $\begin{array}{c}\text { Beta Mass } \\
\text { (mg) }\end{array}$ & $\begin{array}{l}\text { Tare } \\
\text { Wt. } \\
\text { (mg) }\end{array}$ & $\begin{array}{c}\text { Tare Date } \\
\text { Wt. }\end{array}$ & $\begin{array}{c}\text { Gross } \\
\text { Wt. } \\
\text { (mg) }\end{array}$ & $\begin{array}{c}\text { Gross Date } \\
\text { Wt. }\end{array}$ & $\begin{array}{c}\text { Mass } \\
\text { Loading } \\
\text { (mg) }\end{array}$ & Comments & $\begin{array}{c}\text { Loading } \\
\left(\mathrm{mg} \mathrm{cm}^{-2}\right)\end{array}$ \\
\hline $10-0406$ & -0.0467 & 0.4396 & $-2.748 \mathrm{E}-12$ & $4.996 \mathrm{E}-12$ & 115.3 & $3 / 9 / 2010$ & 116.0 & $3 / 24 / 2010$ & 0.7 & Light Dust & 0.0530 \\
\hline $09-2717$ & 0.0664 & 0.7479 & $3.906 \mathrm{E}-12$ & $8.499 \mathrm{E}-12$ & 103.1 & 8/25/2009 & 104.0 & 9/18/2009 & 0.9 & Light Dust & 0.0682 \\
\hline $10-0508$ & 0.1795 & 0.0438 & $1.056 \mathrm{E}-11$ & $4.977 \mathrm{E}-13$ & 103.6 & $3 / 9 / 2010$ & 104.5 & $4 / 7 / 2010$ & 0.9 & Tan & 0.0682 \\
\hline $10-0585$ & 0.0541 & 0.2969 & $3.182 \mathrm{E}-12$ & $3.374 \mathrm{E}-12$ & 95.0 & $4 / 14 / 2010$ & 95.9 & $5 / 4 / 2010$ & 0.9 & Very Light Tan & 0.0682 \\
\hline $10-0584$ & -0.0869 & -0.0683 & $-5.115 \mathrm{E}-12$ & $-7.765 \mathrm{E}-13$ & 117.9 & $4 / 14 / 2010$ & 118.8 & $5 / 4 / 2010$ & 0.9 & Very Light Tan & 0.0682 \\
\hline 09-1961 & 0.0362 & -0.0373 & $2.131 \mathrm{E}-12$ & $-4.235 \mathrm{E}-13$ & 117.3 & $5 / 12 / 2009$ & 118.3 & $6 / 1 / 2009$ & 1.0 & Light color & 0.0758 \\
\hline 09-1965 & 0.0386 & -0.3416 & $2.273 \mathrm{E}-12$ & $-3.882 \mathrm{E}-12$ & 94.9 & $5 / 12 / 2009$ & 95.9 & $6 / 1 / 2009$ & 1.0 & Brown color & 0.0758 \\
\hline 09-1964 & -0.1098 & 0.3711 & $-6.461 \mathrm{E}-12$ & $4.217 \mathrm{E}-12$ & 97.5 & $5 / 12 / 2009$ & 98.5 & $6 / 1 / 2009$ & 1.0 & Light color & 0.0758 \\
\hline $10-0803$ & -0.0942 & 0.3152 & $-5.541 \mathrm{E}-12$ & 3.582E-12 & 93.7 & $6 / 3 / 2010$ & 94.8 & $7 / 9 / 2010$ & 1.1 & Light & 0.0833 \\
\hline $09-1958$ & -0.0845 & 0.7392 & $-4.973 \mathrm{E}-12$ & $8.400 \mathrm{E}-12$ & 108.0 & $5 / 12 / 2009$ & 109.1 & $6 / 1 / 2009$ & 1.1 & Light color & 0.0833 \\
\hline 09-1957 & -0.0927 & 0.4118 & $-5.456 \mathrm{E}-12$ & $4.679 \mathrm{E}-12$ & 108.4 & $5 / 12 / 2009$ & 109.5 & $6 / 1 / 2009$ & 1.1 & Light color & 0.0833 \\
\hline $10-0719$ & -0.0845 & -0.0621 & $-4.973 \mathrm{E}-12$ & $-7.059 \mathrm{E}-13$ & 118.6 & $6 / 3 / 2010$ & 119.7 & 6/23/2010 & 1.1 & Very Light & 0.0833 \\
\hline $10-0133$ & -0.1039 & 0.9799 & $-6.109 \mathrm{E}-12$ & $1.114 \mathrm{E}-11$ & 102.3 & $12 / 10 / 2009$ & 103.5 & 12/29/2009 & 1.2 & $\begin{array}{c}\text { Very Light } \\
\text { Brown }\end{array}$ & 0.0909 \\
\hline $10-0404$ & 0.1464 & 1.4289 & $8.612 \mathrm{E}-12$ & $1.624 \mathrm{E}-11$ & 89.8 & $3 / 9 / 2010$ & 91.1 & $3 / 24 / 2010$ & 1.3 & Tan & 0.0985 \\
\hline $09-2292$ & 0.0195 & 0.3084 & $1.149 \mathrm{E}-12$ & 3.505E-12 & 104.6 & 7/8/2009 & 105.9 & 7/22/2009 & 1.3 & LW & 0.0985 \\
\hline $09-2640$ & 0.1562 & 2.5714 & $9.189 \mathrm{E}-12$ & $2.922 \mathrm{E}-11$ & 108.4 & $8 / 11 / 2009$ & 109.7 & $9 / 8 / 2009$ & 1.3 & Dark Dust & 0.0985 \\
\hline 09-1963 & 0.0386 & 0.0466 & $2.273 \mathrm{E}-12$ & $5.294 \mathrm{E}-13$ & 114.0 & 5/13/2009 & 115.4 & $6 / 1 / 2009$ & 1.4 & Light color & 0.1061 \\
\hline
\end{tabular}




\begin{tabular}{|c|c|c|c|c|c|c|c|c|c|c|c|}
\hline Filter ID & $\begin{array}{c}\text { Alpha } \\
\text { RPTD } \\
\text { (pCi) }\end{array}$ & $\begin{array}{c}\text { Beta } \\
\text { RPTD } \\
\text { (pCi) }\end{array}$ & $\begin{array}{c}\text { Alpha } \\
\text { Mass (mg) }\end{array}$ & $\begin{array}{c}\text { Beta Mass } \\
\text { (mg) }\end{array}$ & $\begin{array}{l}\text { Tare } \\
\text { Wt. } \\
\text { (mg) }\end{array}$ & $\begin{array}{c}\text { Tare Date } \\
\text { Wt. }\end{array}$ & $\begin{array}{c}\text { Gross } \\
\text { Wt. } \\
\text { (mg) }\end{array}$ & $\begin{array}{c}\text { Gross Date } \\
\text { Wt. }\end{array}$ & $\begin{array}{c}\text { Mass } \\
\text { Loading } \\
\text { (mg) }\end{array}$ & Comments & $\begin{array}{c}\text { Loading } \\
\left(\mathrm{mg} \mathrm{cm}^{-2}\right)\end{array}$ \\
\hline 09-1962 & 0.0122 & -0.0358 & 7.179E-13 & $-4.069 \mathrm{E}-13$ & 113.1 & $5 / 13 / 2009$ & 114.5 & $6 / 1 / 2009$ & 1.4 & Light color & 0.1061 \\
\hline $10-0665$ & 0.0507 & -0.1087 & $2.984 \mathrm{E}-12$ & $-1.235 \mathrm{E}-12$ & 109.1 & $5 / 10 / 2010$ & 110.5 & $5 / 26 / 2010$ & 1.4 & Very Light & 0.1061 \\
\hline $10-0720$ & 0.0320 & -0.1411 & $1.881 \mathrm{E}-12$ & $-1.604 \mathrm{E}-12$ & 106.6 & $6 / 3 / 2010$ & 108.0 & 6/23/2010 & 1.4 & Very Light & 0.1061 \\
\hline $09-2588$ & -0.0821 & 0.5994 & $-4.830 \mathrm{E}-12$ & $6.812 \mathrm{E}-12$ & 110.2 & $8 / 5 / 2009$ & 111.6 & $8 / 25 / 2009$ & 1.4 & Light Dust & 0.1061 \\
\hline $10-656$ & -0.0966 & 0.0792 & $-5.683 \mathrm{E}-12$ & $9.000 \mathrm{E}-13$ & 103.3 & $4 / 14 / 2010$ & 104.7 & 5/26/2010 & 1.4 & Light Brown & 0.1061 \\
\hline $10-0804$ & -0.0689 & 0.1200 & $-4.050 \mathrm{E}-12$ & $1.364 \mathrm{E}-12$ & 96.7 & $6 / 3 / 2010$ & 98.1 & 7/9/2010 & 1.4 & Light & 0.1061 \\
\hline $09-2293$ & 0.6328 & 0.2159 & $3.722 \mathrm{E}-11$ & $2.453 \mathrm{E}-12$ & 109.8 & $7 / 8 / 2009$ & 111.3 & 7/22/2009 & 1.5 & LW & 0.1136 \\
\hline $09-2641$ & 1.2100 & 7.7134 & $7.118 \mathrm{E}-11$ & $8.765 \mathrm{E}-11$ & 107.6 & $8 / 11 / 2009$ & 109.2 & $9 / 8 / 2009$ & 1.6 & Dark Dust & 0.1212 \\
\hline $09-2616$ & 0.0024 & 0.0264 & $1.421 \mathrm{E}-13$ & $3.000 \mathrm{E}-13$ & 120.2 & $8 / 19 / 2009$ & 121.8 & $9 / 2 / 2009$ & 1.6 & Light Dust & 0.1212 \\
\hline $09-2617$ & 0.1672 & 0.2093 & $9.837 \mathrm{E}-12$ & $2.378 \mathrm{E}-12$ & 122.9 & $8 / 19 / 2009$ & 124.5 & $9 / 2 / 2009$ & 1.6 & Light Dust & 0.1212 \\
\hline $10-0658$ & -0.0966 & 0.4472 & $-5.683 \mathrm{E}-12$ & $5.082 \mathrm{E}-12$ & 97.3 & $5 / 10 / 2010$ & 98.9 & $5 / 26 / 2010$ & 1.6 & Light Brown & 0.1212 \\
\hline $10-0664$ & 0.1672 & 0.0081 & $9.837 \mathrm{E}-12$ & $9.218 \mathrm{E}-14$ & 104.4 & $5 / 10 / 2010$ & 106.1 & $5 / 26 / 2010$ & 1.7 & Very Light & 0.1288 \\
\hline $10-0662$ & 0.0242 & -0.3292 & $1.421 \mathrm{E}-12$ & $-3.741 \mathrm{E}-12$ & 114.2 & $5 / 10 / 2010$ & 115.9 & $5 / 26 / 2010$ & 1.7 & Light Brown & 0.1288 \\
\hline $10-0405$ & 0.2560 & 4.0050 & $1.506 \mathrm{E}-11$ & $4.551 \mathrm{E}-11$ & 91.1 & $3 / 9 / 2010$ & 92.9 & $3 / 24 / 2010$ & 1.8 & Dark Gray & 0.1364 \\
\hline $09-2180$ & 0.2729 & 0.1351 & $1.605 \mathrm{E}-11$ & $1.536 \mathrm{E}-12$ & 107.6 & 6/29/2009 & 109.4 & 7/16/2009 & 1.8 & LW & 0.1364 \\
\hline $10-0663$ & 0.0507 & 0.0466 & $2.984 \mathrm{E}-12$ & $5.294 \mathrm{E}-13$ & 111.0 & $5 / 10 / 2010$ & 112.9 & $5 / 26 / 2010$ & 1.9 & Very Light & 0.1439 \\
\hline $09-2181$ & -0.0615 & 0.1055 & $-3.620 \mathrm{E}-12$ & $1.199 \mathrm{E}-12$ & 93.5 & 6/29/2009 & 95.5 & 7/16/2009 & 2.0 & LW & 0.1515 \\
\hline 09-1959 & 0.3197 & 1.3400 & $1.881 \mathrm{E}-11$ & $1.523 \mathrm{E}-11$ & 106.5 & $5 / 12 / 2009$ & 108.5 & $6 / 1 / 2009$ & 2.0 & Light color & 0.1515 \\
\hline
\end{tabular}




\begin{tabular}{|c|c|c|c|c|c|c|c|c|c|c|c|}
\hline Filter ID & $\begin{array}{c}\text { Alpha } \\
\text { RPTD } \\
\text { (pCi) }\end{array}$ & $\begin{array}{c}\text { Beta } \\
\text { RPTD } \\
\text { (pCi) }\end{array}$ & $\begin{array}{c}\text { Alpha } \\
\text { Mass (mg) }\end{array}$ & $\begin{array}{c}\text { Beta Mass } \\
\text { (mg) }\end{array}$ & $\begin{array}{l}\text { Tare } \\
\text { Wt. } \\
\text { (mg) }\end{array}$ & $\begin{array}{c}\text { Tare Date } \\
\text { Wt. }\end{array}$ & $\begin{array}{l}\text { Gross } \\
\text { Wt. } \\
\text { (mg) }\end{array}$ & $\begin{array}{c}\text { Gross Date } \\
\text { Wt. }\end{array}$ & $\begin{array}{c}\text { Mass } \\
\text { Loading } \\
\text { (mg) }\end{array}$ & Comments & $\begin{array}{l}\text { Loading } \\
\left(\mathrm{mg} \mathrm{cm}^{-2}\right)\end{array}$ \\
\hline $10-0657$ & 0.0639 & 0.9198 & $3.761 \mathrm{E}-12$ & $1.045 \mathrm{E}-11$ & 95.8 & $4 / 14 / 2010$ & 97.8 & 5/26/2010 & 2.0 & $\begin{array}{c}\text { Very Light } \\
\text { Brown }\end{array}$ & 0.1515 \\
\hline 09-1078 & 0.7801 & 15.0448 & $4.589 \mathrm{E}-11$ & $1.710 \mathrm{E}-10$ & 95.5 & $2 / 10 / 2009$ & 97.6 & $2 / 25 / 2009$ & 2.1 & Dark Brown & 0.1591 \\
\hline $10-0660$ & -0.0966 & 0.4472 & $-5.683 \mathrm{E}-12$ & $5.082 \mathrm{E}-12$ & 102.2 & $5 / 10 / 2010$ & 104.5 & $5 / 26 / 2010$ & 2.3 & Medium Brown & 0.1742 \\
\hline $09-2566$ & -0.0869 & -0.1242 & $-5.115 \mathrm{E}-12$ & $-1.412 \mathrm{E}-12$ & 108.6 & $7 / 22 / 2009$ & 110.9 & $8 / 12 / 2009$ & 2.3 & LW & 0.1742 \\
\hline $09-1960$ & 0.1513 & 7.5727 & $8.902 \mathrm{E}-12$ & $8.605 \mathrm{E}-11$ & 97.6 & $5 / 12 / 2009$ & 100.1 & $6 / 1 / 2009$ & 2.5 & Brown color & 0.1894 \\
\hline $10-0666$ & 0.1672 & 0.4948 & $9.837 \mathrm{E}-12$ & $5.623 \mathrm{E}-12$ & 106.1 & $5 / 10 / 2010$ & 108.6 & $5 / 26 / 2010$ & 2.5 & Very Light & 0.1894 \\
\hline 09-1071 & 0.0242 & -0.0559 & $1.421 \mathrm{E}-12$ & $-6.353 \mathrm{E}-13$ & 114.0 & $2 / 11 / 2009$ & 116.6 & $2 / 25 / 2009$ & 2.6 & Light Brown & 0.1970 \\
\hline $10-0661$ & 0.1844 & 5.9441 & $1.085 \mathrm{E}-11$ & 6.755E-11 & 96.7 & $5 / 10 / 2010$ & 99.5 & $5 / 26 / 2010$ & 2.8 & Dark Brown & 0.2121 \\
\hline 10-0659 & 0.3074 & 0.9961 & $1.808 \mathrm{E}-11$ & $1.132 \mathrm{E}-11$ & 108.8 & $5 / 10 / 2010$ & 111.9 & $5 / 26 / 2010$ & 3.1 & Medium Brown & 0.2348 \\
\hline $09-2565$ & -0.1098 & -0.0732 & $-6.461 \mathrm{E}-12$ & $-8.322 \mathrm{E}-13$ & 109.2 & $7 / 22 / 2009$ & 112.4 & 8/12/2009 & 3.2 & LW & 0.2424 \\
\hline 09-1828 & -0.0580 & 0.0528 & $-3.410 \mathrm{E}-12$ & $6.000 \mathrm{E}-13$ & 117.8 & $4 / 1 / 2009$ & 126.5 & 4/15/2009 & 8.7 & $\begin{array}{c}\text { Very Light } \\
\text { Brown }\end{array}$ & 0.6591 \\
\hline 09-1877 & 0.0217 & -0.0435 & $1.279 \mathrm{E}-12$ & $-4.941 \mathrm{E}-13$ & 96.0 & $4 / 15 / 2009$ & 111.7 & $4 / 29 / 2009$ & 15.7 & Light color & 1.1894 \\
\hline $09-1878$ & -0.0541 & 0.8793 & $-3.182 \mathrm{E}-12$ & $9.992 \mathrm{E}-12$ & 76.8 & $4 / 15 / 2009$ & 99.4 & $4 / 29 / 2009$ & 22.6 & Brown color & 1.7121 \\
\hline 09-1829 & 0.1771 & 0.5191 & $1.042 \mathrm{E}-11$ & $5.899 \mathrm{E}-12$ & 88.1 & $4 / 1 / 2009$ & 128.6 & $4 / 15 / 2009$ & 40.5 & Light Brown & 3.0682 \\
\hline
\end{tabular}




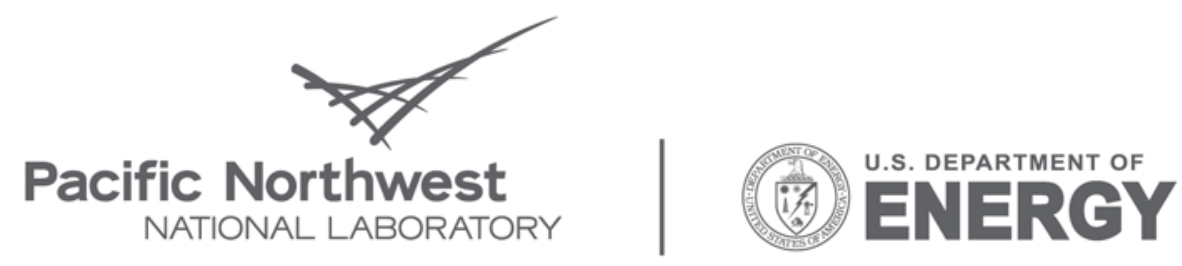

Proudly Operated by Battelle Since 1965

902 Battelle Boulevard

P.O. Box 999

Richland, WA 99352

1-888-375-PNNL (7665)

www.pnl.gov 